\title{
Constitutional Recognition: within a colonial framework
}

\author{
Diane Songco
}

University of Technology Sydney, Faculty of Arts and Social Sciences, PO Box 123, Ultimo

NSW 2007, Australia.diane.p.songco@student.uts.edu.au

Constitutional recognition of Indigenous Australians has been a longstanding national movement reflective of the international struggle of Indigenous communities within a colonial framework. The Uluru Statement from the Heart, delivered at the 2017 National Constitutional Convention, addressed to the Australian public, called for support in the creation of constitutional reforms to build on changes made in the 1967 Referendum. Glen Sean Coulthard's Red Skin, White Masks takes a difference stance on recognition for Indigenous peoples, specifically citing First Nations peoples in North America. In understanding the goals of the Uluru Statement and the arguments raised in Red Skin, White Masks, constitutional recognition may begin to address vital problems such as the dispossession of Indigenous land and lack of inclusion in state politics, but its existence as part of the settler-colonial governance will always act as a deterrent for true decolonization.

Indigenous Australians saw written inclusions in state legislature with the 1967 Referendum, but its aftermath lacked the actual implementation of change for Aboriginal and Torres Strait Islander communities. This symbolic rather than substantial change is reflective of why Coulthard challenges the notion of Indigenous recognition in the colonial framework. Indigenous communities must 'decolonize on our own terms; without the permission of the state or opinions of settlers, as colonial recognition politics only appear to address colonial history but will never fully relinquish state control (2014, p. 154). We see this with First Nations and Native American tribes in Canada and America, respectively, who have selfgovernance over designated territories but whose land rights are still infringed upon by the government for access to oil and water. The Uluru Statement from the Heart is a call to action for constitutional recognition for Indigenous Australians, and though it remains vague in the implementation and changes to legislative wording for potential recognition. It nonetheless outlines steps towards inclusive reform, namely the need for a First Nations Voice and Makarrata commission. Establishing the Voice and commission will begin to address the 'structural nature of our problem', and constitutional reforms will serve to 'empower our people and take a rightful place in our own country'. Recognition may begin the process in CC) Copyright 2019 by the author. This is an Open Access article distributed under the terms of the Creative Commons
Attribution 4.0 Unported (CC BY 4.0) License (https://creativecommons.org/licenses/by/4.0/), allowing third parties to copy and redistribut
the material in any medium or format and to remix, transform, and build upon the material for any purpose, even commercially, provided the
original work is properly cited and states its license. outstanding student works. 
finding solutions for issues regarding stolen children and incarceration numbers, but its existence as part of the constitution of a colonial legislature will prevent proper reparations from ever being made. When self-determination exists within the colonial framework, it is impossible to decolonize Indigenous communities.

\section{References}

Coulthard, Glen Sean. 2014, Red Skin, White Masks: Rejecting the Colonial Politics of Recognition, University of Minnesota Press, Canada.

'Uluru Statement from the Heart', 2017, viewed 5 June 2019.

The University of Melbourne, 'Uluru Statement from the Heart: Information Booklet', The University of Melbourne, viewed 5 June 2019, $<$ https://law.unimelb.edu.au/_data/assets/pdf_file/0005/2791940/Uluru-Statement-from-theHeart-Information-Booklet.pdf>. 